\title{
Model of Relationship Marketing and Power Asymmetry in Indonesia Retail Industry
}

\author{
Anton A. Setyawan ${ }^{1}$, Basu Swastha Dharmmesta ${ }^{2}$, BM Purwanto $^{3}$ and Sahid Susilo \\ Nugroho $^{4}$
}

\begin{abstract}
:
This paper discuss empirical model of business relationship in Indonesia retail industry. Empirical framework of this paper based on relationship marketing concept and power imbalance of retail industry. The purpose of this study is to assess the effect of Power asymmetry and relationship marketing to supplier and retailer economic performance in a business relationship. Result of this paper is empirical framework to analyze Indonesia retail industry. We analyze our empirical model by using Path Analysis. Samples of this study are retailers and suppliers in three major cities in Indonesia, they are Semarang, Surakarta and Jogjakarta. Our unit analysis is dyadic based on the nature concept of relationship marketing proposed by Morgan and Hunt (1994). Main construct of business relationship and technical model of estimation to conduct research about relationship marketing and power imbalance in Indonesia retail industry is also discussed.
\end{abstract}

Key Words: relationship marketing, power asymmetry, retail industry, trust, commitment.

\footnotetext{
${ }^{1}$ Prodi Manajemen Fakultas Ekonomi dan Bisnis, Universitas Muhammadiyah Surakarta, anton.setyawan@ums.ac.id, anton4setyawan@gmail.com, Basu Swastha Dharmmestha, BM Purwanto, Sahid Susilo, Prodi Manajemen Fakultas Ekonomi dan Bisnis Universitas Gadjah Mada

${ }^{2}$ Prodi Manajemen Fakultas Ekonomi dan Bisnis, Universitas Muhammadiyah Surakarta, anton.setyawan@ums.ac.id, anton4setyawan@gmail.com, Basu Swastha Dharmmestha, BM Purwanto, Sahid Susilo, Prodi Manajemen Fakultas Ekonomi dan Bisnis Universitas Gadjah Mada

${ }^{3}$ Prodi Manajemen Fakultas Ekonomi dan Bisnis, Universitas Muhammadiyah Surakarta, anton.setyawan@ums.ac.id, anton4setyawan@gmail.com, Basu Swastha Dharmmestha, BM Purwanto, Sahid Susilo, Prodi Manajemen Fakultas Ekonomi dan Bisnis Universitas Gadjah Mada

${ }^{4}$ Prodi Manajemen Fakultas Ekonomi dan Bisnis, Universitas Muhammadiyah Surakarta, anton.setyawan@ums.ac.id, anton4setyawan@gmail.com, Basu Swastha Dharmmestha, BM Purwanto, Sahid Susilo, Prodi Manajemen Fakultas Ekonomi dan Bisnis Universitas Gadjah Mada
} 


\section{INTRODUCTION}

Relationship marketing in the context of exchange agreement between two organizations becomes ultimate business strategy. Gronroos (1994) identifies there is a shift paradigm in marketing, from marketing mix to relationship marketing. It means the focus of marketing activities has change from gaining new customers to maintaining existing customers (Ravald and Gronroos, 1996). Morgan and Hunt (1994) notify relationship marketing concept originally based on business to business relational exchange. Research in relationship marketing has spread in many areas of marketing, such as retail industry (Dickson and Zhang, 2004; Ramaseshan et al., 2006), banks (Colgate and Alexander, 1998; Ndubisi, 2007), service and hospitality industry (Pressey and Mathews, 2000), construction industry (Jiang et al., 2012) and food industry (Suvanto, 2012).

Peterson and Balasubramanian (2002) identify several issues in retailing research which is important to investigate. Coordination with suppliers or manufacturer consider important to investigate based on contracts, trust and promises (Peterson and Balasubramanian, 2002). Knee (2002) identifies there are five challenges in retail strategies those are branding strategy, human resource development, retailer growth, customer relationship and performance. Those arguments result a conclusion there is an important notes for marketing scholars to investigate business relationship in retail industry.

Dawson (2000) proposes strategic roles of retail industry as distribution channel which connected manufacturer to end customers. It means that retail industry plays a significant role in the distribution process of goods and services. Retailer is connector between manufacturer and end customers. This unique position affects type of business relationship of retailers. They have obligations to maintain long term relationship with customers and suppliers simultaneously.

Strategic roles of retail industry as distribution channel of goods and services have important implication for retailers. Retailers have power and control to their partners due to their role in economics structure (Dawson, 2000; Quin and Doherty, 2000; Doherty and Alexander, 2006). Maloni and Benton (2000) distinguish power of firm into two bases of power, they are coercive and non-coercive power. Coercive power is power of firm as result of coercion, while non-coercive power emerge from several aspects of firm, such as expert, legal, referent, reward and traditional (Maloni and Benton, 2000).

Indonesia is one of emerging economies in Asia with rapid growth of retail industry. This country benefit 6,3 percent average of economic growth as a result of high domestic consumption rate. Retail industry contributes 10 percent of Indonesia's annual product domestic growth in the past 15 years. This industry also absorb more 
than 18,9 million labor of Indonesia. It means this industry is second largest labor absorption economic sector in Indonesia with agriculture as the first.

This paper discuss empirical model of business relationship in Indonesia retail industry. Empirical framework of this paper based on relationship marketing concept and power imbalance of retail industry. The purpose of this study is to assess the effect of Power asymmetry and relationship marketing to supplier and retailer economic performance in a business relationship. Result of this paper is empirical framework to analyze Indonesia retail industry. We analyze our empirical model by using Path Analysis. Samples of this study are retailers and suppliers in three major cities in Indonesia, they are Semarang, Surakarta and Jogjakarta. Our unit analysis is dyadic based on the nature concept of relationship marketing proposed by Morgan and Hunt (1994). Main construct of business relationship and technical model of estimation to conduct research about relationship marketing and power imbalance in Indonesia retail industry is also discussed.

\section{RELATIONSHIP MARKETING CONCEPT}

Ravald and Gronroos (1996) explain the core of relationship marketing is relationship or maintain relationship with its micro environment, such as suppliers, market intermediaries, the public and also end customers. Ravald and Gronroos (1996) argue that the idea of relationship marketing is to generate loyalty and it will results a stable and mutual long term relationship. Morgan and Hunt (1994) define relationship marketing is all activities to establish, develop and maintain successful relational exchange. Berry (1983) defines relationship marketing is attracting and maintaining customers in the multi service organization. Gummeson (1991) explains definition of relationship as building relationship which involves promises offering, maintaining relationship by fulfilling promises and improving relationship by offer new promises on the condition the old ones has been fulfilled.

Morgan and Hunt (1994) argue key concept of relationship marketing rely on trust and commitment. Those two constructs also known as key mediating variables (Morgan and Hunt, 1994). Garbarino and Johnson (1999) found that trust and commitment were key concept in previous research in relationship marketing theory.

\section{Concept of Trust}

Moorman et al. (1992) define trust as a firm's willingness to rely on an exchange partner in whom one has confidence. Trust in the business relationship involves belief that partners will fulfill their promises and also they will perform positive outcomes (Ryu et al., 2008). Trust represent perception of credibility and kindness of an organization or person (Doney and Canon, 1997).

In term of business relationship, trust is a tool for buyer and seller to cooperate in the collaborative situation to overcome conflict and build power of each party (Morgan and Hunt, 1994). Crossby et al., (1990) explain trust emerge when buyer develop an attitude of understanding with seller and belief that they will take action on behalf of 
buyer interests. Morgan and Hunt (1994) propose trust is implication of feeling belief and safe in a relationship with result strong commitment of a long term relationship.

Hefferman (2004) classifies three components of trust, they are:

1. Credibility component. This component related with competence and expertise to meet purpose of business relationship.

2. Integrity component. This component concerned with willingness of partners to hold on their promises to other party.

3. Benevolence component. This component concerned with how partners will make a justification to accommodate any changes in the business relationship.

Morgan and Hunt (1994) explain trust through concept of belief and reliability. Trust is level of belief as a result of perception of reliability and honestly of business partner. In the implementation of relationship strategy, trust is the ultimate foundation of stable business relationship (Garbarino and Johnson, 1999). Buyer evaluate their trust to supplier separately, therefore in a business to business relationship trust refers to perceived credibility and benevolence of suppliers (Doney and Cannon, 1997; Suvanto, 2012).

\section{Concept of Commitment}

According to Allen and Meyer (1990) organizational commitment is individual feeling of obligation to stay with the organization as result of internalization process of normative value. Tellefsen and Thomas (2005) modify definition of commitment when it related with exchange relationship between two or more organizations. Commitment in a business relationship is organization feeling of obligation to stay with the business relationship resulting from perceived benefit of each party (Tellefsen and Thomas, 2005).

Cooper et al. (2005) proposed that marketer tend to build commitment based on emotional attachment instead of economic motivation. This transformation shows importance of commitment construct in relationship marketing research. Lilijander (1999) identifies commitment as an early stage of loyalty. Ndubisi (2007) found that commitment is a result of satisfaction.

Allen and Mayer (1990) classify commitment into three aspects, they are:

3.1 Affective commitment related with feeling of belonging or emotionally attachment aspect.

3.2 Normative commitment is concerned with obligations that members of business relationship

3.3 Continuance commitment related with consideration of switching cost of product or partners in business to business relationship.

Commitment is complement of consumer's psychology and also future definition of loyalty and proud to product or organization (Ekelund and Sharma, 2001). Lilijander (1999) notifies commitment as early form of loyalty. Tellefsen and Thomas (2005) 
proposed that in a case of business relationship, commitment has three elements. First, commitment is a continuous process. Commitment involves implicit and explicit understanding among business partners that they will involved in a long term business relationship with unpredicted problems and potential conflicts. Second, commitment reflects desire of both parties. Commitment based on personal choice instead of legal obligation. Third, value is driver of commitment. Business partners arrange long term relationship with consideration of benefit from the deal.

\section{POWER ASYMMETRY IN BUSINESS RELATIONSHIP}

Discussion of organization's power related with resource dependence theory proposed by Pfeffer and Salancik (1987). Resource dependence theory proposed organization's ability to survive depends on their capability to maintain their critical resources from external environment. In order to reduce uncertainty, organizations try to re-structure their dependence with several tactics. Those tactics include unilateral tactic. In this tactic, organization slice their difficulties with their resources by reduce their dependence to certain resources. They are looking for alternative resource or build coalition with other organization. Second tactic is direct reconstruction of organization's dependence, such as partner's cooptation to share information or accomplish merger and acquisition.

Power or in numerous literatures often labeled influence strategy is source of bargaining position of organization against their partners (Kim, 2000; Ramaseshan, et al. 2006). Power is capability to influence other (Butaney and Wortzel, 1988; Ramaseshan, et al. 2006). Organizations have different source of power. Ratnasingam (2000) classified power of organizations by source of power. Non coercive power is organization's power as a result of reward, expertise, recommendation and legitimateness. Coercive power is a derivation of organization's capability to give sanction and punishment to partners.

Ramaseshan et al., (2006) provide excellent example of coercive and non coercive power usage by company to their partner. In their research, Ramaseshan et al., (2006) find department store in China give pressure to their tenant in order to achieve certain behavior (i.e obedience to department store's rules). Failure of achieving certain behavior could result punishment to tenant. Department store uses coercive power to enhance involvement of tenant in advertising campaign, service quality and other operational aspects. Department store in China use non coercive power by assisting and rewarding tenants, whenever business deal has been achieved. Non coercive power related with procedure of information sharing between department store and their tenants (Ramaseshan et al., 2006).

Butaney and Wortzel (1988) identify characteristic of consumer's or manufacturer power are similar with those belongs to channel distribution. Power could be derived from degrees of satisfaction to channel member achievement and relative resource of power of channel members (El Ansery and Stern, 1972). In the context of 
manufacturer and retailer influence strategy, Porter (1980) explained manufacturer dominate influence strategy to retailer when market structure is oligopoly, they already arrange customer's switching cost and product is an important part of end product or production process. On the other hand, consumer's industry dominates influence strategy in business relationship when they purchase a lot of products, product has low switching cost and they have clear market information.

El-Ansery and Stern (1972) classify power in distribution channel into two sources; they are distributor and manufacturer power. Distributor power is distributor level of independence to determine marketing decision about manufacturer's product. Manufacturer power is manufacturer's characteristic which has capability to influence distributor and retailer in the market. In the context of channel conflict, there is a strong interaction of those two powers which often resulted negative for business relationship continuance (Butaney and Wortzel, 1988).

In the context of business relationship between two companies there is certain condition when each company has different level of power, for example, when modern retailer has relationship with SME in a supplier-retailer relationship. Hingley (2005) investigates the issue of power imbalance in British Food Industry. He found that relationship building is possible in the condition of asymmetric power between two companies. Weaker parties are tolerant with the condition of Power asymmetry (Hingley, 2005). On the other hand, Morgan and Hunt (1994) has different result, in their research of relationship marketing in varied industry in US, they found that Power asymmetry has negative effect on relationship quality. Maloni and Benton (2000) have similar result in their works of analyzing the effect of different source of power to buyer-seller relationship in US automotive industry. Maloni and Benton (2000) conclude that different source of power has differed effect on business relationship. Coercive and legal power has negative effect on business relationship, while reward, expert and referent have positive effect on such construct. Ramaseshan et al., (2006) assess the role of Power asymmetry in the business relationship between supermarket and its tenants in China. The result shows that when Power asymmetry between supermarket and its tenants emerged, the level of satisfaction of weaker party in the business relationship is decreased (Ramaseshan et al., 2006).

H1 Power asymmetry has negative effect on company's trust with their partners.

H2 Power asymmetry has negative effect on company's commitment with their partners.

\section{RELATIONSHIP MARKETING AND BUSINESS PERFORMANCE}

Relationship marketing strategy has an ultimate goal to improve business performance of each companies involved in business relationship. Morgan and Hunt (1994) provide concept and empirical example of relationship marketing strategy in industry supply chain. Johnson (1999) analyzes the effect of strategic alliances to 
business performance among firms with business similarity. The result shows that antecedents of strategic alliances are dependence, relationship age, business continuity expectation, flexibility and relationship quality. Johnson (1999) proposed strategic alliances as mediating variable to analyze effect of dependence, relationship age, business continuity expectation, flexibility and relationship quality to business performance.

Debate of business performance measurement in business research occurs due to the complexity of performance definition (Percy, 1995; Ruiz, 2000). In business to business relationship, company usually applies economic performance, such as selling volume, profitability and company growth (Kim, 2000; Ruiz, 2000; Ramaseshan et al., 2006). There are also different measurement on business performance such as consumer's loyalty (Hallowell, 1996) and satisfaction (McDougall and Levesque, 2000). Keiningham et al., (2006) show relationship among business performance measurement in U.S specialty goods retailer. Satisfaction of both employee and customer has positive effect on changes in sales volume. Megicks (2007) in his work on analyze SME retailer's performance employs a mix of performance measurement. Megicks (2007) propose a combination of ROI growth, merchandise turn over and customer retention as retailer performance standards.

In this paper, we employ economic performance to assess business relationship performance. There are several reasons to do such thing. First, our findings in our preliminary work show that SME companies in Indonesia measure their performance based on their economic achievement. There are only few of them which conduct strategic performance measurement such as customer satisfaction, loyalty and retention. Second, we are facing a wide variety of companies in different industry as supplier for each retailer. Economic performance could gain similarity in performance measurement as result of such issue.

H3 Company's trust to their partners has positive effect on supplier's economic performance.

H4 Company's trust to their partners has positive effect on retailer's economic performance.

H5 Company's commitment with their business relationship has positive effect on supplier's economic performance.

H5 Company's commitment with their business relationship has positive effect on retailer's economic performance.

\section{CONCEPTUAL MODEL: POWER ASYMMETRY AND RELATIONSHIP MARKETING}

In this paper we proposed model of Power asymmetry and relationship marketing in Indonesia retail industry. We developed the model based on Morgan and Hunt 
(1994) commitment-trust theory and model of inter-firm power proposed by Kim (2000). Figure 1 shows relationship between construct in the model.

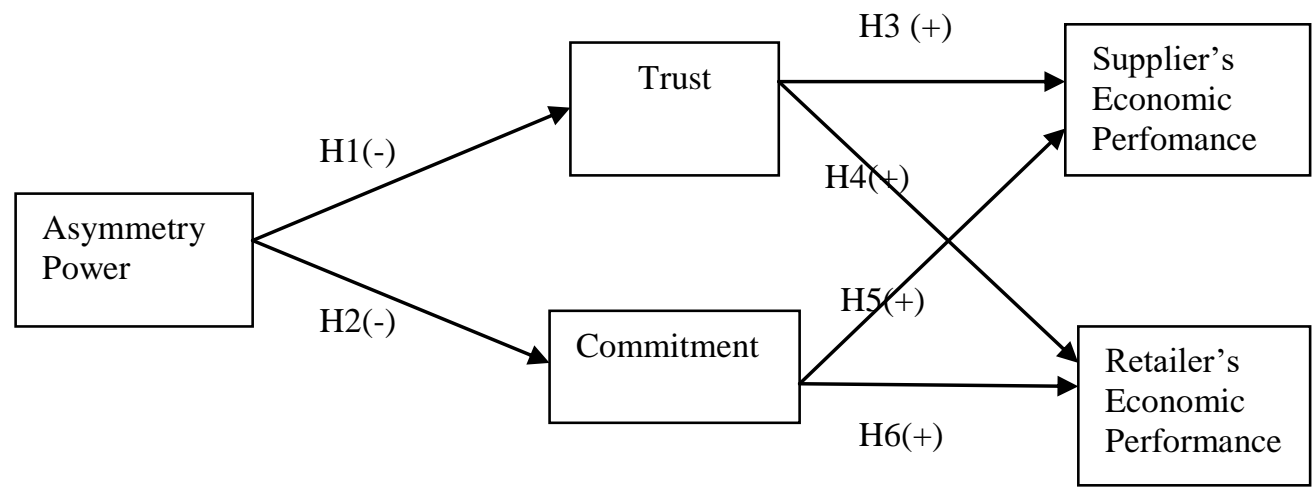

Source: Developed from Morgan and Hunt (1994), Kim (2000).

Figure 1. Conceptual Model of Power asymmetry And Relationship Marketing

\section{INDONESIA RETAIL INDUSTRY WITH OLIGOPOLISTIC MARKET STRUCTURE}

Retail industry shows significant contributions to Indonesia's economy. Table 1 shows current development of retail industry transactions and it contribution to Indonesia’s GDP from 2000 to 2012.

Table 1. Selected Indicators of Indonesia’s Retail Industry 2000-2012.

\begin{tabular}{cccc}
\hline Year & $\begin{array}{c}\text { Transactions } \\
\text { (IDR billion) }\end{array}$ & $\begin{array}{c}\text { GDP at Current } \\
\text { Price } \\
\text { (IDR billion) }\end{array}$ & $\begin{array}{c}\text { \% to GDP at } \\
\text { Current Price }\end{array}$ \\
\hline 2000 & 194969.92 & 1264919 & 15,4 \\
2001 & 223966.65 & 1684280 & 13,2 \\
2002 & 245564.35 & 1863275 & 13,17 \\
2003 & 263635.42 & 2045853 & 12,8 \\
2004 & 288112.8 & 2273142 & 12,67 \\
2005 & 337229.5 & 2729708 & 12,35 \\
2006 & 386872.5 & 2777501 & 13,9 \\
2007 & 464149.3 & 3015303 & 15,3 \\
2008 & 551343.7 & 4948688.4 & 11,8 \\
2009 & 585722.8 & 5603871.2 & 11,1 \\
2010 & 702278.3 & 6422918.2 & 10,6 \\
2011 & 102210 & 7427100 & 13,8 \\
2012 & 119705 & 7872726 & 13,7 \\
\hline
\end{tabular}

Source: Indonesia Central Bank, (2007); Asian Development Bank (2006), Indonesia Statistical Bureau (2012). 
Table 1 gives information that retail industry gives second largest contributions to Indonesia GDP, while manufacture industry is the first. The average GDP contribution is 13 percent, while agriculture sector suffer decreasing level of GDP contributions, from 23 percent in 1987 to 15 percent in 2004. Retail industry absorbs large number of workforce. According to Indonesian Statistical Bureau in 2012, there are 18,9 millions workforce in the industry. 45 percent from 22,7 millions of business organizations in Indonesia is retailer (Indonesia Statistical Bureau, 2012).

Based on the type of organization, there are two kinds of retailer in Indonesia, they are modern and traditional retailer. Modern retail enjoys high growth of market rate. It has 37 percent of growth in market share since 2009 (Widjaja, 2010). According to Widjaja (2010), modern retailer in Indonesia has $8-10 \%$ growth of outlets, while traditional retailer has only $1 \%$ growth from $2003-2008$.

Retail industry in Indonesia has grown into more oligopolistic market since it dominated by modern retailer. Widjaja (2010) analyzes that every segments in Indonesia retail industry has different market leader. In 2008, Indomaret and Alfamaret dominated $43,2 \%$ and $40,8 \%$ of minimarket market share. These two retailers are local brand even though they considered modern retailer. In supermarket segment, $76 \%$ of the market share dominated by 6 modern retailers, they are Hero, Carrefour, Super Indo, Foodmart, Ramayana and Yogya. Carrefour also dominated $50 \%$ market share of hypermarket segment, followed by Hypermart with 22,1\% of market share and Giant with only $18,5 \%$ of it.

\section{RESEARCH METHODS}

\section{Design of Study}

We conduct survey to analyze our conceptual model. The survey based on cities in Indonesia with rapid growth of retail business, they are Yogyakarta, Semarang and Surakarta. Retail industry growth of selected cities is $162 \%$ on average during 2008 2009 (Widjaja, 2010). To determine our respondents we use data provided by Indonesian Retail Association (APRINDO) and Ministry of SME and Cooperation Office.

\section{Population and Sample}

Population of this study is modern and traditional retailers with their suppliers. Our sample design is dyadic. Research traditions in relationship marketing suggest dyadic approach to analyze business relationship in business to business setting (Palmer, et al., 2005). Constructs in this study are dyadic in nature. Morgan and Hunt (1994) in their works employ dyadic approach to analyze commitment and trust. Palmer et al.,(2005) state that commitment and trust and other relational construct are dyadic in nature. Our respondents are paired of retailer and supplier in Yogyakarta, Semarang and Surakarta based on APRINDO data. 
We apply purposive sampling method in this study. The characteristic of respondents are companies which has 3 years duration of business relationship with its suppliers and size of companies varied from small-midsized and micro entrepreneur to modern retailer and manufacturer. We use enumerator to collect data. Technically, our enumerator meet respondent and ask them to fulfill self administered questionnaire. We distributed more than 300 questionnaires for respondents. The result, we obtain 204 dyads of supplier-retailer relationship completed their questionnaire.

\section{Measurement}

We develop measurement of constructs from Johnson (1999), Kim (2000), Bennet et al., (2005) and Ramaseshan et al., (2006). There are 5 constructs in this study; they are Power asymmetry, commitment, trust, supplier's economic performance and retailer's economic performance. Table 2 shows dimension of each construct in the study.

Table 2. Dimension of Power asymmetry and Relationship Marketing Construct

\begin{tabular}{|c|c|c|c|}
\hline No & Constructs & Dimension & Source \\
\hline 1. & Power asymmetry & $\begin{array}{l}\text { Quality control, price } \\
\text { policy, payment period, } \\
\text { reward and punishment. }\end{array}$ & $\begin{array}{l}\text { Ramaseshan } \text { et al. } \\
\text { (2006); Kim }(2000) \text {, } \\
\begin{array}{l}\text { Maloni and Benton } \\
(2000)\end{array}\end{array}$ \\
\hline 2. & Commitment & $\begin{array}{l}\text { Age of business } \\
\text { relationship, Business } \\
\text { relationship intensity, } \\
\text { switching cost of business } \\
\text { partnership and alternative } \\
\text { choice of business partner. }\end{array}$ & $\begin{array}{l}\text { Wu et al. (2004); } \\
\text { Srinivasan and } \\
\text { Moorman (2005). }\end{array}$ \\
\hline 3 & Trust & 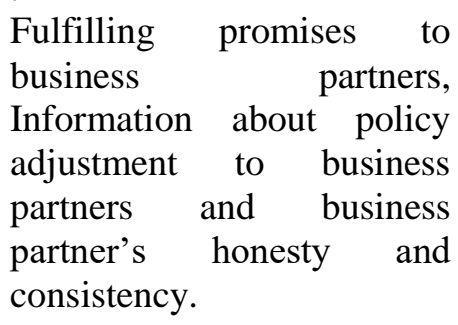 & $\begin{array}{l}\text { Wu et al. (2004); Kim } \\
(2000), \text { Ryu et al. } \\
(2008) .\end{array}$ \\
\hline 4 & $\begin{array}{l}\text { Supplier's } \\
\text { Economic } \\
\text { Performance }\end{array}$ & $\begin{array}{l}\text { growth, profit } \\
\text { market } \text { share } \\
\text { and company }\end{array}$ & $\begin{array}{l}\text { Ruiz, 2000; Kim,2000; } \\
\text { Corsten and Kumar, } \\
\text { 2005, Ramaseshan et al. } \\
\text { (2006); Neill and Rose } \\
(2006) ; \quad \text { Hallowel } \\
(1996)\end{array}$ \\
\hline 5 & Retailer's & growth, & Ruiz, 2000; Kim,2000; \\
\hline
\end{tabular}


Economic

Performance growth, market share growth and company growth.
Corsten and Kumar, 2005, Ramaseshan et al. (2006); Neill and Rose (2006); (1996)

Our unit analysis is dyadic. Our dyadic analysis based on a combination of average and difference measurement method proposed by Kim (2000). It also follows Bigne and Blesa (2003) to measure each perception of dyadic members. Assessment of Power asymmetry is to calculate difference perception of suppliers and retailers about their partner's influence and control strategy. Trust and commitment are measured by calculating average perception of suppliers and retailers. Suppliers and retailers economic performance measured separately for each member of dyads.

\section{ANALYSIS AND RESULTS}

\section{Validation and Reliability of Constructs}

There is a unique challenge in measuring validation and reliability of constructs in this study, since our measurement based on average and difference value of constructs. We assess validation and reliability of Power asymmetry based on the difference between supplier and retailer perception of the construct, while trust and commitment measurement based on average value of supplier and retailer perception. However, supplier and retailer economic performance measured based on each member of dyads perception about the issue. Table 3 shows result of validation and reliability of constructs.

Table 3. Construct and Indicator Validity and Reliability

\begin{tabular}{|c|c|c|c|c|c|c|}
\hline \multirow[t]{2}{*}{ Construct Indicator } & \multirow{2}{*}{$\begin{array}{l}\text { Cronbach } \\
\text { Alpha }\end{array}$} & \multicolumn{5}{|c|}{ Factor Loadings } \\
\hline & & $\mathbf{1}$ & 2 & 3 & 4 & 5 \\
\hline $\begin{array}{l}\text { Power asymmetry } \\
\text { Our business partner has } \\
\text { capability to influence our } \\
\text { price policy. } \\
\text { Our business partner has } \\
\text { capability to punish our } \\
\text { company. } \\
\text { Our business partner could } \\
\text { give our company warning } \\
\text { because of our service } \\
\text { failure. } \\
\text { Commitment } \\
\text { It is very difficult for our } \\
\text { company to switch business } \\
\text { partner }\end{array}$ & 0.606 & & & $\begin{array}{l}0,729 \\
0,754 \\
0,796\end{array}$ & & $\begin{array}{l}0,539 \\
0,667 \\
0,612\end{array}$ \\
\hline
\end{tabular}




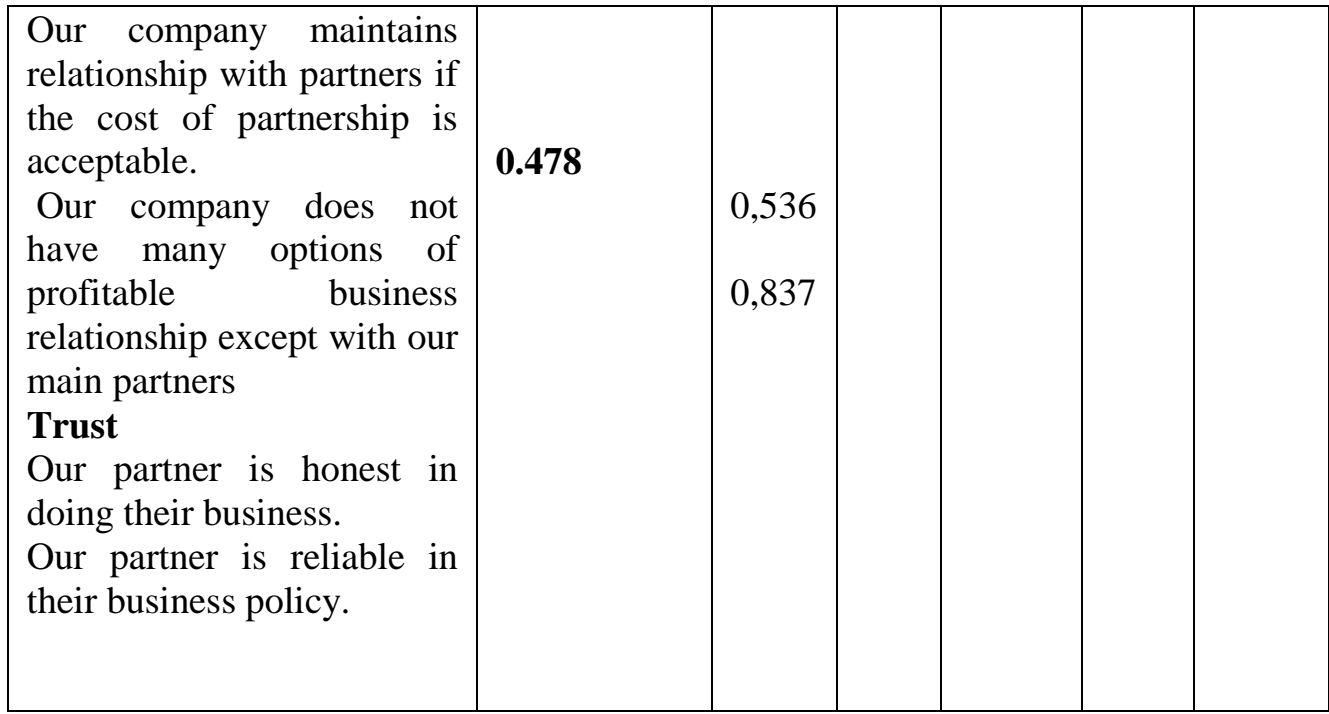

Table 3(Continued). Construct and Indicator Validity and Reliability

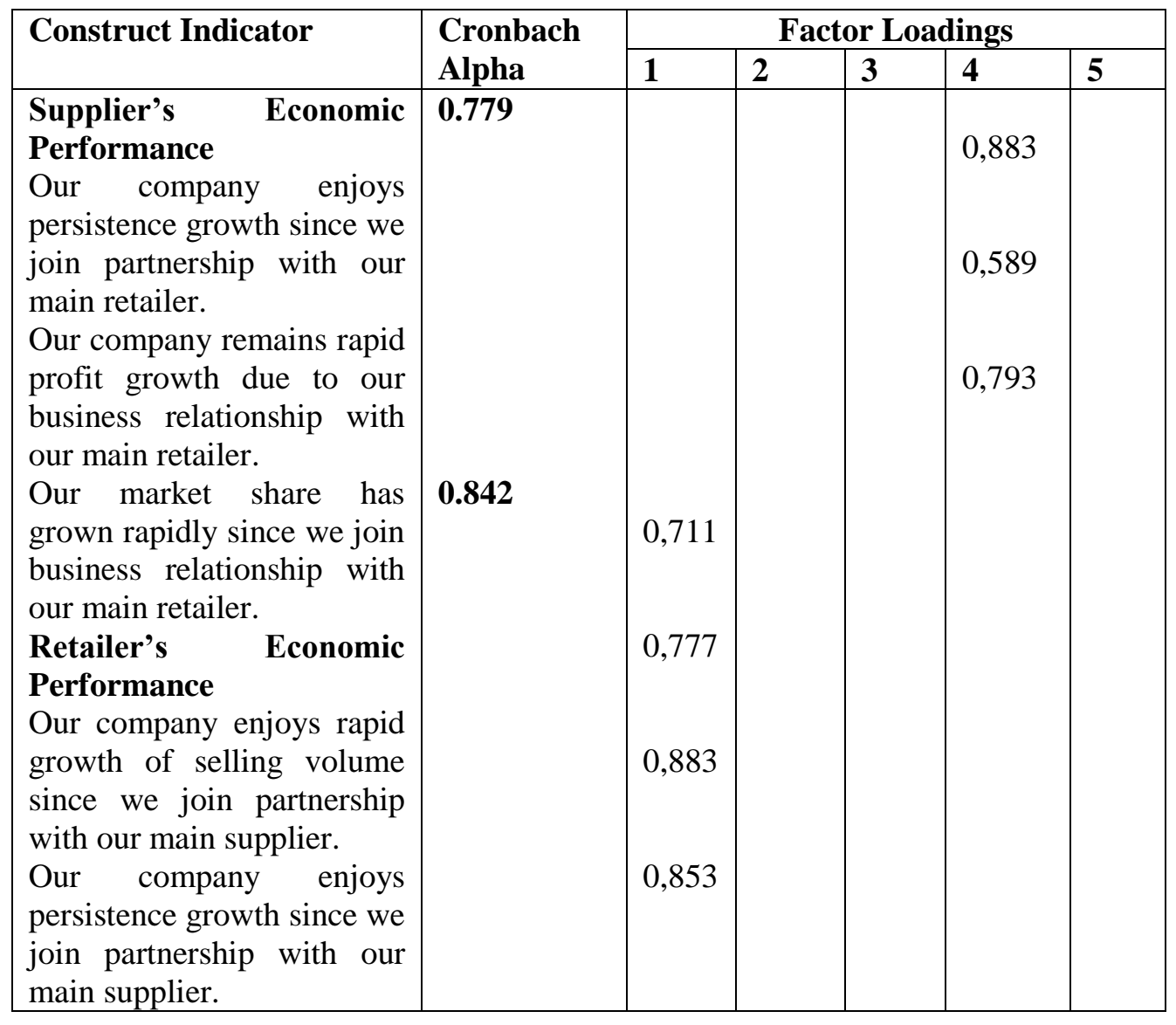


Our company remains rapid profit growth due to our business relationship with our main supplier.

Our market share has grown rapidly since we join business relationship with our main supplier.

\begin{tabular}{|l|l|l|l|l|l|}
\hline & & & & & \\
& & & & & \\
\end{tabular}

Result of validity and reliability measurement show that construct and indicator of this study has fulfilling minimum value required in the factor loading and Cronbach Alpha. Trust is the only construct which does not have minimum required value with only 0.478 Cronbach Alpha. The conclusion is that trust has low internal consistency.

\section{Descriptive Statistics and Nomological Validity}

We measure descriptive statistic to gain information about mean of each construct. We also determine nomological validity to predict relationship among construct in the models. Nomological validity based on correlation analysis of each construct in this study. Diamantopoulos (1999) suggests nomological validity is not just analyzing correlation without any theoretical background, even though the result is not a rigorous model. We follow this suggestion by analyzing correlation among construct based on relationship marketing and power theory. Table 4 shows result of descriptive statistic analysis and nomological validity of constructs in this study.

Table 4. Descriptive Statistic and Nomological Validity Result

\begin{tabular}{|c|c|c|c|c|c|}
\hline Constructs & 1 & 2 & 3 & 4 & 5 \\
\hline Mean & 0.9395 & 4.0748 & 3.9816 & 4.1483 & 3.9730 \\
\hline Std Dev & 0.68461 & 0.59368 & 0.67774 & 0.70432 & 0.81504 \\
\hline 1.Power asymmetry & 1.000 & & & & \\
\hline 2.Trust & $-0.140 *$ & 1.000 & & & \\
\hline 3.Commitment & -0.082 & $0.445 * *$ & 1.000 & & \\
\hline $\begin{array}{l}\text { 4.Supplier's Economic } \\
\text { Performance }\end{array}$ & $0.237 * *$ & $0.304 * *$ & $0.164 *$ & 1.000 & \\
\hline $\begin{array}{l}\text { 5.Retailer's Economic } \\
\text { Performance }\end{array}$ & 0.045 & $0.564 * *$ & $0.282 * *$ & $0.394 * *$ & 1.000 \\
\hline
\end{tabular}

Note: ** Correlation is significant at 0.01 levels

* Correlation is significant at 0.05 levels

Nomological validity shows that every constructs in this study are significantly correlated except Power asymmetry with commitment and retailer's economic 
performance. Table 4 also gives interesting information about relationship among construct. Power asymmetry has positive and significant correlation with supplier's economic performance, while it does not show similar result with retailer's economic performance.

\section{Path Analysis Results}

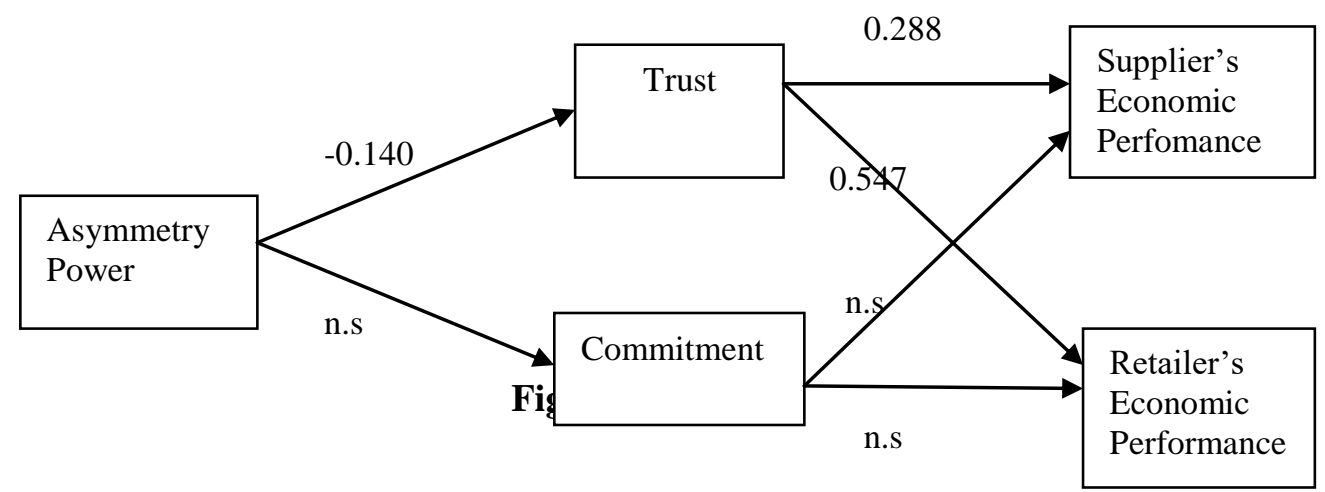

Figure 2. Empirical Model of Power asymmetry and Relationship Marketing in Retail Industry

Table 5 shows goodness of fit of the empirical model in this study.

Table 5. Goodness of Fit of Empirical Model

\begin{tabular}{|c|c|c|c|}
\hline Goodness Of Fit & Cut Off Value & Estimation Result & Notes \\
\hline Chi Square & $\begin{array}{l}\text { Small value is } \\
\text { acceptable }\end{array}$ & 20.022 & Good \\
\hline Probability & $\geq 0,05$ & 0.000 & Good \\
\hline GFI & $\geq 0,90$ & 0.964 & Good \\
\hline AGFI & $\geq 0,90$ & 0.728 & Marginal \\
\hline CFI & $\geq 0,95$ & 0.896 & Moderate \\
\hline RMSEA & $\leq 0,08$ & 0.211 & Marginal \\
\hline CMIN/DF & $\leq 5,00$ & 10.001 & Marginal \\
\hline
\end{tabular}

Path analysis result gives information that power asymmetry has significant negative effect to company trust to their business partners with standardized regression weights -0.140 (critical ratio-2.019). Trust has significant positive effect to both supplier and retailer economic performance with standardized regression weights 0.288 (critical ratio 3.861 ) and 0.547 (critical ratio 8.457). Power asymmetry does not have significant effect to commitment with business relationship (critical ratio 1.173). Commitment is also does not have significant effect to supplier's economic performance (critical ratio 0.476 ) nor retailer's economic performance (critical ratio 0.602). 
Goodness of fit of empirical model in this study is moderate. Chi square value and Goodness of Fit Index (GFI) are appropriate, while CFI considered marginal, however, RMSEA and CMIN/DF are marginal. Our conclusion is theoretical model of Power asymmetry and relationship marketing in the retail industry is supported empirically. Table 6 shows resume of hypothesis testing in this study.

Table 6. Hypothesis Testing Resume

\begin{tabular}{|l|c|c|}
\hline Hypothesis & Critical Ratio & Result \\
\hline $\begin{array}{l}\text { H1 Power asymmetry has negative } \\
\text { effect on company's trust with their } \\
\text { partners. }\end{array}$ & -2.019 & Supported \\
$\begin{array}{l}\text { H2 Power asymmetry has negative } \\
\text { effect on company's commitment with } \\
\text { their partners. }\end{array}$ & -1.173 & Not Supported \\
$\begin{array}{l}\text { H3 Company's trust to their partners } \\
\text { has positive effect on supplier's }\end{array}$ & 3.861 & Supported \\
$\begin{array}{l}\text { economic performance. } \\
\text { H4 Company's trust to their partners } \\
\text { has positive effect on retailer's } \\
\text { economic performance. }\end{array}$ & 8.457 & Supported \\
$\begin{array}{l}\text { H5 Company's commitment with their } \\
\text { businessrelationship has positive effect } \\
\text { on supplier's economic performance. }\end{array}$ & 0.476 & Not Supported \\
$\begin{array}{l}\text { H5 Company's commitment with their } \\
\text { business relationship has positive effect } \\
\text { on retailer's economic performance. }\end{array}$ & 0.602 & Not Supported \\
\hline
\end{tabular}

\section{DISCUSSIONS AND CONCLUSSIONS}

\section{Power Asymmetry in Indonesia Retail Industry}

Finding in this study show that Power asymmetry has negative effect to company trust to their partners. Trust represents perception of credibility and benevolence of organization or individual (Doney and Canon, 1997). Trust is also a symbol of beliefs that the trusted will make accurate statement, fulfilling their promise and act for the interest of its partners (Moorman, et al, 1993). Morgan and Hunt (1994) proposed trust is the basic of business to business relationship. Trust is a tool for buyer and seller to join a collaborative situation, handling conflict and building each partner power (Morgan and Hunt, 1994).

Power asymmetry has result a decreased in trust level of company to their partner. This condition is a sign that there is an exploitative business relationship between supplier and retailer in this study. One side has dominates business relationship to another. Correlation analysis of nomological validity in table 4 gives information 
that Power asymmetry has positive significant correlation with supplier's economic performance, while it doesn't show the same sign for retailer's economic performance. We figure that suppliers have power domination in their business relationship with retailers. Our dyadic samples show that most our respondents are business relationship between large or multinational suppliers with SME retailers. This explains supplier's power domination which result an exploitative business relationship. This finding is comparable with Morgan and Hunt (1994) conclusion that coercive power has significant negative effect to relationship constructs.

\section{Relationship Marketing in Retail Industry}

This study confirms trust and commitment theory proposed by Morgan and Hunt (1994). Trust plays a significant role as key mediating variable in business to business relationship. In this study it shows that trust has mediated relationship between Power asymmetry and performance. However, commitment failed as mediating variable in the relationship among those constructs. This finding is minor difference compare to Morgan and Hunt (1994). In this study trust is the only dimension of relationship marketing which become key mediating variable, while Morgan and Hunt (1994) trust and commitment succeed in playing that role. We conclude that in a condition of exploitative business relationship, both supplier and retailer still keep their trust to their partners.

In the other hand, commitment is not significant as a mediating variable in assessment of Power asymmetry and relationship marketing. Ramaseshan et al., (2006) conclude that commitment in a business relationship has time orientation and development stage based on each party evaluation of the process and the result of it. In this study, we conclude that due to the existence of Power asymmetry which result an exploitative business relationship, supplier and retailer evaluate their business and consider switching business partners. In this situation, long term mutually benefit business relationship is not possible for both supplier and retailer. In this study, company trust to their partners will result an increasing economic performance, since if a company beliefs that their partner will do business by considering their economic interest than it will do the same thing for their partners. In a long term it will be a win-win situation for both sides.

\section{IMPLICATIONS OF THE STUDY}

\section{Relationship Marketing School of Thought and Macro Marketing Development}

Palmer et al., (2005) explains there are three schools of thought in relationship marketing research; they are Nordic School, Industrial or International Marketing and Purchasing Group (IMP) and Anglo Australian Group. This study gives contribution to the development of IMP group in the implementation of relationship marketing framework in business to business setting. Findings in this study should encourage marketing scholars to develop Trust-Commitment theory in the retail industry setting and supply chain management. 
Our findings in this study show that Power asymmetry and relationship marketing is a potential tool to analyze distribution system of a country. Shapiro (2006) classifies research in marketing with macro level of aggregation such as distribution system into macro marketing research. Yi and Jaffe (2007) with their works on the impact of distribution channel and retail industry to China's economic growth has similar issue and contribution with this study. Extended implementation of relationship marketing to macro marketing issue such as economic growth, distribution system, poverty and SME competitiveness invite marketing scholars into challenging empirical research. This study provides entry point to study such issue especially in emerging and developing economics background of the research.

\section{Business Partnership and SME Development}

Power asymmetry has significant negative effect to company trust with their partners. This finding has an implication that Power asymmetry should not be appear in the process of business partnership building. Long term business relationship with mutual benefit is not possible when a company has power domination to its partner.

In our correlation analysis, this study reveals that Power asymmetry has positive significant correlation with supplier's economic performance, and it has no correlations with retailer's economic performance. This finding shows sign of exploitation in the business relationship between supplier and retailer. In this study, SME retailers have been exploited by large and multi-national supplier. It shows there is an unfair trade in Indonesia retail industry. In the context in SME development policy, unfair trade will be a disadvantageous situation. Indonesia's administration should manage their regulation to protect SME from large and multinational company exploitation.

\section{REFERENCES}

Allen, N.J and Meyer, J.P (1990), "The Measurement and Antecedents of Affective, Continuance and Normative Commitment to The Organization", Journal of Occupational Psychology, 63: 1-18.

Bennet, R. Hartel, C.E.J and McColl-Kennedy, J.R (2005),"Experience as a Moderator of Involvement and Satisfaction on Brand Loyalty in a Business to Business Setting 02314R”, Industrial Marketing Management, 34:97-107.

Berry, L.L. (1983) "Relationship Marketing" in : Emerging Perspectives on Services Marketing, American Marketing Association, Chicago: 25-28.

Bigne, E. and Blesa, A. (2003), "Market Orientation, Trust And Satisfaction In Dyadic Relationships: A Manufacturer-Retailer Analysis", International Journal Of Retail and Distribution Management, 31(11) : 574-590.

Butaney,G. and Wortzel, L.H (1988),"Distributor Power Versus Manufacturer Power: The Customer Role", Journal of Marketing, $52: 52-63$.

Colgate, M and Alexander, N (1998). "Banks, Retailers and Their Customers: A Relationship Marketing Perspective", International Journal of Bank Marketing. 16(4) : 144-152. 
Cooper, M.J, Upton, N. and Seaman, S, (2005), "Customer Relationship Management: A Comparative Analysis of Family and Non-family Business Practices", Journal of Small Business Management, 43 (3) :242-256.

Corsten, D. and Kumar, N. (2005), "Do Suppliers Benefit from Collaborative Relationships with Large Retailers? An Empirical Investigation of Efficient Consumer Response Adoption", Journal of Marketing, 69: 80-94.

Crosby, L.A., Kenneth R. E., and Cowles, D. (1990),"'Relationship Quality In Services Selling: An Interpersonal Influence Perspective", Journal of Marketing, 54(3): 68-81.

Dawson, J. (2000), "Viewpoint: Retailer, Power, Manufacturer Power, Competition and Some Question of Economic Analysis", International Journal of Retail and Distribution Management, 28 (1): 5-8.

Diamantopoulos, A. (1999), "Viewpoint Export Performance Measurement: Reflective Versus Formative Indicators", International Marketing Review, 16 (6) : 444-457.

Dickson, M.A. dan Li Z. (2004), "Supplier-retailer Relationships in China's Distribution Channel for Foreign Brand Apparel", Journal of Fashion Marketing and Management, 8 (2): 201-220.

Doherty, A.M and Alexander,N. (2006), "Power and Control In International Retail Franchising", European Journal Of Marketing. 40 (11/12) :1292-1316.

Doney, P.M and Cannon, J.P. (1997). "An examination of trust in buyer-seller relationships", Journal of Marketing, 61(2): 35- 51.

Ekelund, C. and Sharma, D.D (2001), "The Impact of Trust on Relationship Commitment: A Study of Standardized Products in a Mature Industrial Market," Kristianstaad University, Research Report.

El Ansery, A. and Stern, L.W (1972), "Power Measurement in the Distribution Channel", Journal of Marketing Research ,9:47-52.

Garbarino, E. and Johnson, M.S. (1999) "The Different Roles of Satisfaction, Trust, and Commitment in Customer Relationships", Journal of Marketing, 63(2) :70-87.

Gonroos, C (1994), "From Marketing Mix To Relationship Marketing: Towards a Paradigm Shift in Marketing", Management Decision, 32 (2): 4-20.

Gummesson, E. (1991), "Marketing Orientation Revisited: The Crucial Role of the PartTime Marketer", European Journal of Marketing, 25(2) :.60-75.

Hallowell, R. (1996), "The Relationship of Customer Satisfaction, Customer Loyalty and Profitability: An Empirical Study", International Journal of Service Industry Management, 7( 4) : 27-42.

Heffernan, T. (2004), "Trust Formation in Cross-Cultural Business to Business Relationships", Qualitative Market Research: An International Journal, 7 (2) :114-125.

Hingley, M.K (2005), "Power Imbalance in UK Agri Food Supply Channels: Learning To Live With The Supermarkets?", Journal Of Marketing Management, 21: 63-68.

Jiang, Z., Henneberg, S.C and Naude P. (2012). "Supplier Relationship Management In The Construction Industry: The Effects Of Trust And Dependence", Journal of Business \& Industrial Marketing, 27/1:3-15.

Keiningham, T L, Aksoy L, Cooil B, Peterson K and Vavra, TG (2006), “A Longitudinal Examination of The Asymmetric Impact of Employee and Customer Satisfaction on Retail Sales", Managing Service Quality, 16(5): 442-459.

Kim, K. (2000), "On Interfirm Power, Channel Climate and Solidarity in Industrial Distributor-Supplier Dyads", Journal of The Academy of Marketing Science, 28 (3): 388-405.

Knee, C. (2002), "Learning From Experience: Five Challenges For Retailers", International Journal of Retail and Distribution Management, 30 (11): 518-529. 
Liljander, V.(1999), The Importance of Internal Relationship Marketing for External Relationship Success, in Thorsten Hennig-Thurau and Ursula Hansen, Eds., Relationship Marketing: Gaining Competitive Advantage through Customer Satisfaction and Customer Retention, Springer Verlag: Berlin, 159-192.

Maloni, M. and Benton, W.C (2000), "Power Influences In The Supply Chain”, Journal of Business Logistics, 21 (1): 49-73.

McDougall, G.H.G and Levesque, T. (2000), "Customer Satisfaction with Services: Putting Perceived Value into The Equation", Journal of Services Marketing, 14( 5) :392-410.

Megicks, P. (2007), "Levels of Strategy and Performance in UK Small Retail Business", Management Decision, 45 (3): 484-502.

Moorman, C., Desphande, R. and Zaltman, G. (1993),"'Factors Affecting Trust In Market Research Relationships", Journal Of Marketing, 57(1) :81-101.

Morgan, R.M. and Hunt, SD. (1994) 'The commitment-trust theory of relationship marketing', Journal of Marketing, 58(3): 20-38.

Ndubisi, N.O (2007)," Relationship marketing and customer loyalty", Marketing Intelligence \& Planning, 25 (1): 98-106.

Neill, S. and Rose, G.M (2006), "The Effect of Strategic Complexity on Marketing Strategy and Organizational Performance", Journal of Business Research, (59):1-10.

Palmer, R. Lindgreen A. and Vanhamme. J (2005), "Relationship Marketing: Schools of Thought and Future Research Directions", Marketing Intelligence and Planning, 23 (3) : 313-330.

Percy, N.F. (1995), “Marketing And Strategy Fit Together”, Management Decision, 33 (1) : 42-47.

Peterson, R.A dan Balasubramain, S. (2002).’Retailing In The $21^{\text {st }}$ Century: Reflections and Prologue To Research", Journal of Retailing 78: 9-16.

Pfeffer J and Salancik, G.R, (1978), The External Control of Organizations, A Resource Dependence Perspective, New York, Stratford Press Inc.

Porter, M.E (1980), Competitive Strategy, New York, The Free Press.

Pressey, A.D and Mathews, B.P. (2000). "Barriers To Relationship Marketing In Consumer Retailing", Journal of Services Marketing, 14(3):272-286.

Quinn, B.and Doherty, A.M (2000), "Power and control in international retail franchising ; Evidence from theory and practice", International Marketing Review, 17( 4/5):354-372.

Ramaseshan, B , Yip LC and Pae JH (2006). "Power, Satisfaction and Relationship Commitment in Chinese Store-Tenant Relationship and Their Impact on Performance" Journal of Retailing 82 (1) : 63-70.

Ratnasingam, P.(2000). "The influence of power on trading partner trust in electronic commerce", Internet Research: Electronic Networking Applications and Policy , 10 (1) : 56-62.

Ravald, A and Grönroos, C. (1996). The Value Concept and Relationship Marketing”, European Journal of Marketing, 30 (2) : 19-30.

Ruiz, F.J.M. (2000), "The Supplier-Retailer Relationship in The Context of Strategic Groups", International Journal of Retail and Distribution Management, 28 (2): 93-106.

Ryu , S. Min, S. and Zushi, N. (2008), "The moderating role of trust in manufacturer-supplier relationships", Journal of Business \& Industrial Marketing, 23 (1) :48-58.

Shapiro, S.J. (2006), "Macromarketing: Origins, Development, Current Status and Possible Future Direction", European Business Review, 18 (4): 307-321.

Srinivasan, R. and Moorman,C. (2005), "Strategic Firm Commitments and Rewards for Customer Relationship Management in Online Retailing", Journal of Marketing, 69:193-200. 
Suvanto, H. (2012), "Constructing A Typology Of Trust In Asymmetrical Food Business Relationships", British Food Journal, Vol. 114 No. 7, pp. 926-943.

Tellefsen , T. and Thomas, G.P (2005),"'The antecedents and consequences of organizational and personal commitment in business service relationships", Industrial Marketing Management, 34:23-37.

Widjaja, V (2010), Retail Industry Analysis, Pefindo Credit Rating Indonesia.

Wu, W.Y, Chiag, C.Y, Wu Y.J and Tu, H.J (2004), "The influencing factors of commitment and business integration on supply chain management", Industrial Management \& Data Systems, 104(4) :322-333.

Yi, L. and Jaffe, E.D (2007), "Economic Development and Channel Evolution in The People's Republicc of China", Asia Pacific Journal of Marketing and Logistics, 19 ( 1): 22-39. 